\title{
Bullying in School: Evaluation using CPTED at potential bullying area
}

\author{
Siti Rasidah Md Sakip ${ }^{1,2}$, Azna Abdul Wahab ${ }^{3}$ \\ ${ }^{1}$ Department of Landscape Architecture, Faculty of Architecture, Planning \& Surveying, \\ Universiti Teknologi MARA Perak Branch, Seri Iskandar Campus, 32610, Perak, Malaysia \\ 2 Green Safe Cities Research Group, Universiti Teknologi MARA, Shah Alam Campus,40450, Selangor, Malaysia \\ ${ }^{3}$ Faculty of Architecture, Planning \& Surveying, \\ Universiti Teknologi MARA (UiTM), 40450 Shah Alam, Selangor Darul Ehsan, Malaysia \\ sitir704@uitm.edu.my, azna.abdulwahab@yahoo.com \\ Tel: 019-2798594
}

\begin{abstract}
Bullying in schools is a worrying phenomenon and has an impact on the safety of school children. This paper aims to identify potential spaces of bullying behaviour in the school area. The questionnaire and observation checklist is an instrument to determine the frequency of student bullying in specific spaces of a school. Students from Form One until Form Three are the respondents in this research. Three areas with high rates of Bullying which are toilet, class and canteen. The maintenance element is the most crucial factor that space is not visited by students and potential area of Bullying.
\end{abstract}

Keywords: Bullying, school, physical environment, CPTED

eISSN: 2398-4287 @ 2020. The Authors. Published for AMER ABRA cE-Bs by e-International Publishing House, Ltd., UK. This is an open access article under the CC BYNC-ND license (http://creativecommons.org/licenses/by-nc-nd/4.0/). Peer-review under responsibility of AMER (Association of Malaysian Environment-Behaviour Researchers), ABRA (Association of Behavioural Researchers on Asians) and cE-Bs (Centre for Environment-Behaviour Studies), Faculty of Architecture, Planning \& Surveying, Universiti Teknologi MARA, Malaysia.

DOI: https://doi.org/10.21834/ebpj.v5iSI2.2520.

\subsection{Introduction}

Bullying is a growing social issue that affects millions of students globally. For almost 30 years, bullying among students has been known as a severe problem in school (Roland \& Galloway, 2002). Bullying in schools reflects a part of the more significant issue of violence in society (Atlas \& Pepler, 1998). Previous longitudinal studies have found a consistent and robust relationship between Bullying and later criminality (Andershed, Kerr, \& Stattin, 2001; Min, F. Catalano, P. Haggerty, \& D. Abbott, 2011; Dan Olweus, 2011; Renda, Vassallo, \& Edwards, 2011; Sourander et al., 2011). Bullying behaviour among students is a global phenomenon that not only occurs in Malaysian schools but also occurs in other countries such as Australia, Japan, England and the United States. Bullying makes the lives of its victims miserable. It undermines their confidence and destroys their sense of security. It can also affect children and young people's attendance and progress at school. And there's evidence that, for some people, being bullied regularly as a child can also be linked to emotional problems considered to be a severe problem among the victims which included high levels of anxiety, depression, (Hawker \& Boulton, 2000; Nakamoto \& Schwartz, 2010; Reijntjes Kamphuis, Prinzie, \& Telch, 2010; Ken Rigby, 2003) and suicidal thinking (Rigby 2003; Sourander et al. 2011). Bullying is considered as a pre-criminal where it is a cruel act that invites toward criminal activity in the future (Andershed, Kerr, and Stattin 2001; Min et al. 2011; Olweus 2011; Renda, Vassallo, and Edwards 2011; Sourander et al. 2011). Therefore, Poyner (1983) believes that criminal acts are related to the design and layout of the physical environment. The opportunities that exist in an environment encourage a criminal to act on a targeted victim (Liebermann \& Kruger, 2004). Moreover, in deciding whether or not to commit an act of crime, environmental elements are one of the factors considered by criminals (Anastasia \& John, 2007). In

eISSN: 2398-4287 @ 2020. The Authors. Published for AMER ABRA CE-Bs by e-International Publishing House, Ltd., UK. This is an open access article under the CC BYNC-ND license (http://creativecommons.org/licenses/by-nc-nd/4.0). Peer-review under responsibility of AMER (Association of Malaysian Environment-Behaviour Researchers), ABRA (Association of Behavioural Researchers on Asians) and cE-Bs (Centre for Environment-Behaviour Studies), Faculty of Architecture, Planning \& Surveying, Universiti Teknologi MARA, Malaysia.

DOI: https://doi.org/10.21834/ebpj.v5iSI2.2520. 
this regard, this paper aims to identify spaces that students often become victims of bullying as well as to identify the potential areas of Bullying and their relation to the physical environment using the elements of Crime Prevention through Environmental Design (CPTED).

\subsection{Literature Review}

Wi et al., (2009) defined bullying as repeated, ill-negative behaviours by one or more students directed against a student who has difficulty defending himself or herself. Therefore, Bullying will take place when there is an imbalance of power which leads to adverse action and the struggle to defend oneself. Bullying behaviour may take many forms such as physical, verbal, (Olweus and Mortimore 1993) and relational or social Bullying (Crick et al. 1995). Physical Bullying, such as hitting, pushing and kicking, and verbal bullying, such as name-calling and teasing in a hurtful way, are usually considered to be a direct form, while relational Bullying refers to an indirect form of Bullying, such as exclusion and spreading rumours (Espelage, Bosworth, and Simon 2000; Wang, lannotti, and Nansel 2009). Verbal Bullying was the most widely performed type of Bullying (Boulton, Trueman, and Flemington 2002; Mohamad Salleh and Zainal 2014; Rigby 2008) that can be done quietly and covertly where the children can avoid detection and punishment (Atlas and Pepler 1998).

The creation of safe school environments has become a focus of prevention and intervention efforts in response to problems of Bullying in schools. A sense of safety from any danger and perpetration is one of the crucial aspects that drive the quality of life of students. Feeling safe is vital for a student to have a positive learning environment in school. They are feeling unsafe in school impacts mental health, absenteeism and academic success among the bullied (Hughes, Gaines, and Pryor 2014). Schools encounter vulnerabilities to their safety and security in four significant areas; (1) the design, supervision and use of school space (Astor, Meyer, and Behre 1999; Durán-Narucki 2008; Grana et al. 2010; J Waller 2013; Kumar, M. O' Malley, and D. Johnston 2008; Wilcox et al. 2006), (2) the administrative operations and practices of the school (Vidourek, King, and Merianos 2016) (3) the neighbourhoods and surrounding communities served by the school (Bowes et al. 2009; Lee and Ha 2015) and (4) the behavioural characteristics and histories of the students who are enrolled in the school (Atlas and Pepler 1998; Farrington and Ttofi 2011; Mohamad Salleh and Zainal 2014).

The most common locations for student victimization of Bullying are at the playground (Fite et al., 2013; Dan Olweus, 1993; Stephenson \& Smith, 1989), classroom (Atlas \& Pepler, 1998; Rapppaglicci et al., 2004), and hallways (Astor et al., 1999; Stephenson \& Smith, 1989; Vidourek et al., 2016). Certain 'hotspots' that are indicated to be unowned spaces are where the sights of more crime events create greater fear among students (Astor et al., 1999). The presence of ownership of these locations has the potential to drastically decrease the prevalence of victimization in schools (Astor et al., 1999). Through these studies, victimisation occurs most likely when the adults are limited in their abilities to monitor. The school structure may play an essential part in giving a chance for individual children to involve in bullying behaviours (Atlas \& Pepler, 1998). Craig et al. (2000) reported that victimisation is most likely to occur in less structured environments. Studies showed that lower rates of school victimization were associated with the school safety interventions that are focused on improving the physical environment of the school (Johnson, 2009). Johnson (2009) concluded that the physical environment appears to offer intervention opportunities to reduce school victimization.

From the previous study, regarding school crime and influence of environmental design, they had studied the physical features (Wilcox et al. 2006), lighting (Lee and $\mathrm{Ha}$ 2015), land used (Lee and Ha 2015; Wilcox et al. 2006), neighbourhood physical environment (Wilcox et al. 2006) and building condition (Durán-Narucki 2008; Kumar et al. 2008) in the school environment and its effects toward student behaviour. Although most exterior spaces of elementary schools are high visibility areas, the hottest spots were behind the areas of the building which were low invisibility (Lee \& Ha, 2015). A place which is not visible because it is isolated and is obstructed by landscaping and building design are believed to increase the risk of attack, and hence create fear (Lorenc et al., 2013).

\subsection{Methodology}

The site selection for this study is based on the highest number of perpetrators in the age range from 7 to 18 years in crime cases reported by police in the year of 2010 till 2015. Based on the Royal Malaysian Police or Polis Diraja Malaysia (PDRM) statistical report, over 14 states in Malaysia, the state of Selangor has the highest reported number of crimes which involved students (1,503 cases) and followed by the state of Johor with 1,147 cases. With this crime data report, followed by crime data from the State Education Department (Jabatan Pendidikan Negeri-JPN), Selangor has the highest number of cases of discipline in secondary school students within the district. From the ten regions in Selangor, Hulu Langat has been identified to show the highest number of cases of Bullying in secondary schools. Therefore, this study was conducted in four secondary schools in the Hulu Langat district in Selangor due to the highest number of misconduct cases. This is based on the expectation that the higher number of misconduct cases, the higher the probability that Bullying will occur. After Hulu Langat District had been selected as a site study, bullies' crime data from the District Education Unit or Pejabat Pendidikan Daerah (PPD) had been obtained. The data shows 39 schools are under the management of PPD Hulu Langat. Six schools were excluded from the case study selection due to the factors such as boarding school, national type school and government-aided schools. Only 33 public schools were included in the range of the site study. Four schools had been selected from the 33 public schools. These schools were identified to have the highest number of bullying cases which are $A B, B C, C D$ and $D E$ (the school name cannot be disclosed as it is confidential and crucial to preserve the image of the school)

This research was done using the mix method of survey and observation to evaluate the Crime Prevention through Environmental Design (CPTED) elements, while the questionnaire had been distributed to identify the spaces that have the most frequency of Bullying. 
The survey was done in five working days, from 7.20 a.m. until 6.45 p.m. The respondents involved in this study were students from Form One until Form Three. Each class that represents the level has been randomly selected to answer the questionnaire.

\subsection{Questionnaire}

In this study, the measurement to identify the location of the student being bullied (LSBB) are measured using a questionnaire, rated by a Likert scale ranging from $1=$ never, $2=$ once a month, $3=2$ to 3 times a month, $4=$ once a week and $5=2$ to 3 times a week. The validation on the variables is essential to verify that the items of each construct are valid to measure the dimension using the exploratory factor analysis (EFA). EFA is used in the early stages to gather information about the interrelationships among variables (Nunnally, J. C., \& Bernstein, I. H.,1994). The Cronbach's Alpha (a) value was used to determine the level of reliability through the internal consistency for each factor. An item-to-scale value of 0.3 and above was used as the minimum value for a unidimensional scale (De Vaus, D. A., 1986), while the level was considered reliable if the alpha value was 0.6 and above, based on the Devellis, R. F. (1991), criteria. The results of the analysis demonstrated the location of students being bullied (LSBB), involved two dimensions which are the location of victimisation (LOV) and fear of location (FOL). These two dimensions achieved Alpha (a) value level exceeding 0.60 (LOV=0.89, FOL=0.95).

\subsection{Observation through a Checklist}

To examine the effect of the physical environment on school bullying, the variable will be measured based on CPTED elements which were territoriality, surveillance, and maintenance. School-level territoriality is operationalized with two different measures which are symbolization element and ownership element. The aspect is measured based on the number of the component. The indicators of the ownership are sculptures, school field, garden furniture and mural. School-level surveillance is measured based upon the observation of a building on how it will present an opportunity for bullying to occur. The item includes questions about hidden corners, the visibility of the building from another, the provision of lamps, the visibility of the school activity area and the design of the building. The scale was coded $1=$ very dissatisfied which refers to the ability of vision between $0-20$ per cent, $2=$ dissatisfied which refers to the ability of vision between $21-40$ per cent, 3=neither satisfied nor dissatisfied which refers to the ability of vision between $41-60$ per cent, 4=satisfied which refers to the ability of vision between $61-80$ per cent and $5=$ very satisfied which refers between $80-100$ per cent. The output of surveillance can indicate which arrangement of school building could provide the best monitoring towards the student's safety and activity. Meanwhile, school level maintenance is measured by the observation of 7 elements of school disorder. The school disorder includes the presence of graffiti, litter, broken windows, and broken doors. The response of the item is the same as the surveillance scale. The scale had been adapted from Sakip et al. (2012) study on CPTED and fear of crime.

\subsection{Research Method Sampling}

The site selection for the present study is based on the highest number of perpetration ranges from 7 to 18 years old in crime index cases reported by police over five years ago from the year 2010 until September 2015. Table 1 below shows the crime index data in 14 states in Malaysia for the past five years. The highest reported crime index which involved students were in Selangor as much as 1,503 cases and followed by Johor 1,147 cases and Kedah 1,112 cases. Crime cases are more top in Selangor because Selangor is an urban city with high population density and infrastructure of the built environment. Urbanization has created many social problems, and crime has become a common phenomenon in all urban areas (Adel, Salheen, and Mahmoud 2014; Ghani 2017).

Table 1. Crime index involving students in Malaysian states

\begin{tabular}{|c|c|c|c|c|c|c|c|c|}
\hline \multirow{2}{*}{ No } & \multirow{2}{*}{ States } & \multicolumn{6}{|c|}{ Year } & \multirow{2}{*}{ Total } \\
\hline & & 2010 & 2011 & 2012 & 2013 & 2014 & 2015 & \\
\hline 1 & Johor & 148 & 95 & 57 & 379 & 299 & 169 & 1147 \\
\hline 2 & Kedah & 234 & 1552 & 97 & 272 & 205 & 152 & 1112 \\
\hline 3 & Kelantan & 190 & 130 & 94 & 199 & 133 & 105 & 851 \\
\hline 4 & Kuala Lumpur & 108 & 106 & 125 & 147 & 165 & 94 & 745 \\
\hline 5 & Melaka & 53 & 37 & 13 & 125 & 90 & 51 & 369 \\
\hline 6 & Negeri Sembilan & 61 & 47 & 61 & 106 & 160 & 95 & 530 \\
\hline 7 & Pahang & 77 & 56 & 56 & 165 & 173 & 87 & 614 \\
\hline 8 & Perak & 127 & 84 & 90 & 210 & 146 & 114 & 771 \\
\hline 9 & Perlis & 36 & 26 & 49 & 57 & 39 & 25 & 232 \\
\hline 10 & Pulau Pinang & 131 & 86 & 23 & 138 & 63 & 82 & 523 \\
\hline 11 & Sabah & 115 & 60 & 51 & 120 & 76 & 55 & 477 \\
\hline 12 & Sarawak & 121 & 69 & 82 & 137 & 104 & 115 & 628 \\
\hline 13 & Selangor & 369 & 218 & 58 & 269 & 313 & 276 & 1503 \\
\hline \multirow[t]{2}{*}{14} & Terengganu & 92 & 64 & 95 & 159 & 107 & 67 & 584 \\
\hline & Total & 1862 & 1230 & 951 & 2483 & 2073 & 1487 & 10086 \\
\hline
\end{tabular}

Source: The Royal Malaysia Police Bukit Aman, 2015

With the assumption that the number perpetration in school is linear with the number of bullying in school, Selangor was chosen as the location of this study. Besides, the selection of Selangor as site study is relevant due to the news reported in June 2017, the Ministry of Education had listed as many as 402 schools nationwide which have been identified as having disciplinary issues among its students and Selangor states was recorded as having the highest number of bullying cases and the highest number of 'hotspot' schools (Bernama 2017). The data from the Selangor State Education Department was acquired to get the number of misconduct cases in Selangor district schools. Table 2 below showed ten districts in Selangor and Hulu Langat district that were reported to be the highest contributors 
to the number of misconduct cases in Selangor district with 68,248 cases followed by Petaling Perdana with 45,551 cases and Klang with 29,990 cases.

Table 2. Number of misconduct cases in Selangor district

\begin{tabular}{|clccccc|}
\hline \multicolumn{7}{c}{ Year } \\
\hline No & States & 2013 & 2014 & 2015 & 2016 & Total \\
\hline 1 & Sabakk Bernam & 767 & 328 & 945 & 881 & 2921 \\
\hline 2 & Gombak & 3871 & 4723 & 7002 & 3473 & 19069 \\
\hline 3 & Retaling Perdana & 7085 & 9272 & 21757 & 7437 & 45551 \\
\hline 4 & Kuala Langat & 2489 & 2573 & 2267 & 1807 & 9136 \\
\hline 5 & Sepang & 2383 & 5395 & 2227 & 1545 & 11550 \\
\hline 6 & Kuala Selangor & 3845 & 4246 & 3785 & 3695 & 15571 \\
\hline 7 & Hulu Langat & $\mathbf{1 8 2 8 0}$ & $\mathbf{2 0 0 2 9}$ & $\mathbf{1 4 7 9 6}$ & $\mathbf{1 5 1 4 3}$ & $\mathbf{6 8 2 4 8}$ \\
\hline 8 & Klang & 7066 & 8570 & 10250 & 4104 & 29990 \\
\hline 9 & Betaling Utama & 3447 & 6682 & 51363 & 2027 & 17319 \\
\hline 10 & Hulu Selangor & 3368 & 5065 & 7081 & 2948 & 18462 \\
\hline & Total & 52601 & 66883 & 75273 & 43060 & 237817 \\
\hline
\end{tabular}

Source: Selangor State Education Department, 2015

Lastly, bullying data was acquired from District Education Offices in Hulu Langat. Based on the data that had been obtained, 39 schools are under the management of the Hulu Langat District Education Offices. Six schools were excluded from the case study selection due to factors such as boarding school, national type school and government-aided schools. Only 33 public schools were included in the selection of the site study. Based on the statistics of Bullying in Hulu Langat schools, there are four types of Bullying which are verbal Bullying, Physical Bullying, sign bullying and social Bullying. In the year 2013, 72 cases of Bullying were recorded, which increased to 85 cases in the year 2014. The incidents continued to grow in the year 2015 with 104 recorded cases and kept on rising to 159 until July 2016.

As explained in the methodology, four schools were chosen for comparison in the study. Two were indicated to have the highest number of bullying cases which are School $A B$ and $B C$. AB was chosen as the location of the case study because the number of Bullying that occurred suddenly increased in the year 2015 from one case to 10 cases and kept on rising in the year 2016. BC was chosen as the location of the case study due to the bullying cases that are maintained in the same range between 9 to 10 each year. The School of $C D$ and $D E$ were chosen to compare the lowest number of bullying cases to occur. The schools in this study were co-ed schools and comprised of different ethnicities. Towards achieving the objective, 406 students were randomly chosen as respondents from four secondary schools in Hulu Langat Selangor to answer the questionnaire. The respondents were from Form One, Form Two and Form Three students. Previous studies had claimed that students from the lower form tend to be bully-victims compared to upper form students (Due et al., 2005; Fitzpatrick, Dulin, \& Piko, 2007). Those in the top form feel they are old enough and have experienced being bullied. This will lead them to bully other students younger than them. Student's personalities, such as ego, irritability, revenge, and fun, can influence the behaviour of bullies (Salleh \& Zainal, 2014). Once the questionnaires were completed, they were gathered, evaluated and prepared for data entry in Statistical Package for the Social Sciences (SPSS). The researcher will observe the student's movement and engagement during recess and also the school layout to identify the distribution of students at certain places during the break.

\subsection{Result and Discussion}

By reviewing the findings for each of the four schools evaluated in a survey, it displayed the response of 406 respondents regarding the frequency of the occurrence of Bullying and sense of safety at a particular area in schools. As noted previously, Bullying tends to occur in common areas in school which have been identified as 'un-owned spaces'. Throughout the schools, in Table 3, students mostly identified Bullying to happen in the toilet, class and school canteen.

Table 3. The percentage of frequency where students are being bullied

\begin{tabular}{|l|l|l|l|l|l|}
\hline School Area & $\begin{array}{l}\text { Almost Always } \\
(2-3 \text { times a } \\
\text { week) }\end{array}$ & $\begin{array}{l}\text { Often } \\
\text { (Once a } \\
\text { week) }\end{array}$ & $\begin{array}{l}\text { Sometimes } \\
(2-3 \text { times in a } \\
\text { month) }\end{array}$ & $\begin{array}{l}\text { Seldom } \\
\text { (Less than } \\
\text { once a } \\
\text { month) }\end{array}$ & $\begin{array}{l}\text { Almost } \\
\text { Never } \\
\text { (Never) }\end{array}$ \\
\hline Class (No teacher) & 3.0 & 3.2 & 7.2 & 17.6 & 69.1 \\
\hline $\begin{array}{l}\text { Class (With } \\
\text { teacher) }\end{array}$ & 0.7 & 1.0 & 1.5 & 10.9 & 85.9 \\
\hline Open Spaces & 2.0 & 2.2 & 7.5 & 15.4 & 72.9 \\
\hline School corridor & 1.7 & 2.0 & 7.4 & 16.6 & 72.3 \\
\hline $\begin{array}{l}\text { On the route in or } \\
\text { out of school }\end{array}$ & 1.7 & 1.5 & 4.4 & 8.6 & 83.3 \\
\hline Stairways & 1.5 & 1.0 & 6.5 & 14.4 & 76.7 \\
\hline Car Park & 0.7 & 0.5 & 1.5 & 6.2 & 91.1 \\
\hline Canteen & 2.7 & 2.2 & 6.9 & 19.6 & 68.6 \\
\hline Field & 1.0 & 1.2 & 6.7 & 9.9 & 81.2 \\
\hline
\end{tabular}




\begin{tabular}{|c|c|c|c|c|c|}
\hline School Hall & 2.0 & 1.0 & 4.0 & 11.4 & 81.6 \\
\hline Parking motorbike & 2.0 & 1.0 & 2.7 & 4.5 & 89.9 \\
\hline & & & 7.4 & 12.9 & \\
\hline
\end{tabular}

Based on this output, it can be stated that those areas are less noticed by the teacher where it creates an opportunity for the bullies. Although those areas are some of the areas where students gather and meet, Bullying is less noticeable probably because the students were too preoccupied with their activity and will not be too concerned with what was happening in their surroundings.

\subsection{Toilet}

The location of the toilet is always at the end of the school buildings, and this factor makes it a hotspot of Bullying. These areas are often an extremely private part of the school building and are unsupervised by teachers and staff. A lot of anti-social behaviour occurs when pupils are allowed to assemble in a private toilet area. One of the schools $(\mathrm{CD})$ had a toilet that was in bad condition and had provided a paid-toilet in the school for the convenience of users as an alternative. It was observed that compared to the paid-toilet, the other toilets were mostly smelly and dirty. The figure below showed the condition of the bathroom stated. The peeling of paint and damaged water pipe can be seen clearly.

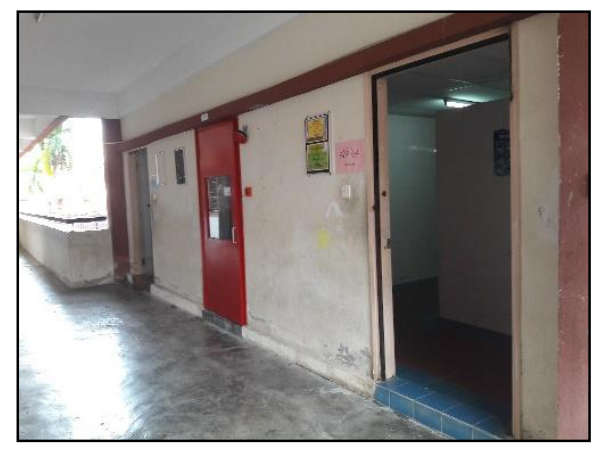

Fig 1. The condition of toilet in $A B$
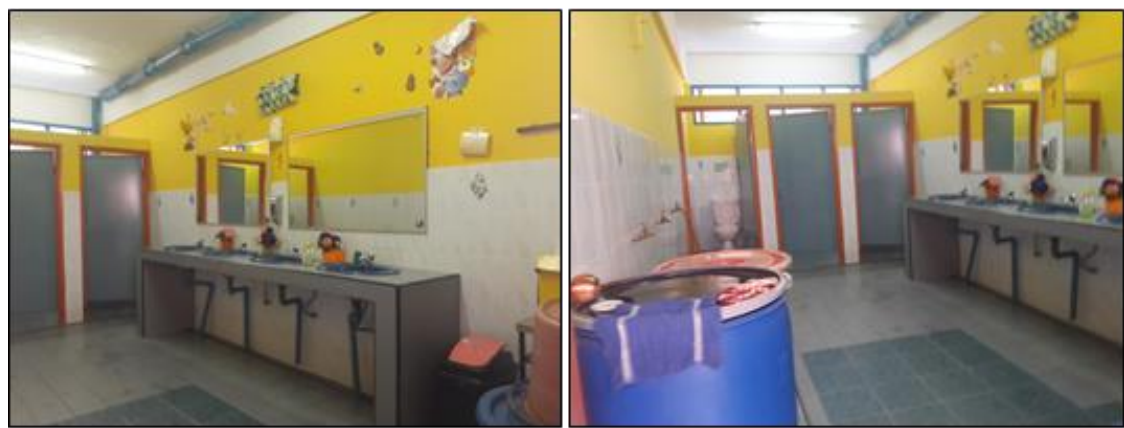

Fig 2. The condition of toilet in $\mathrm{BC}$
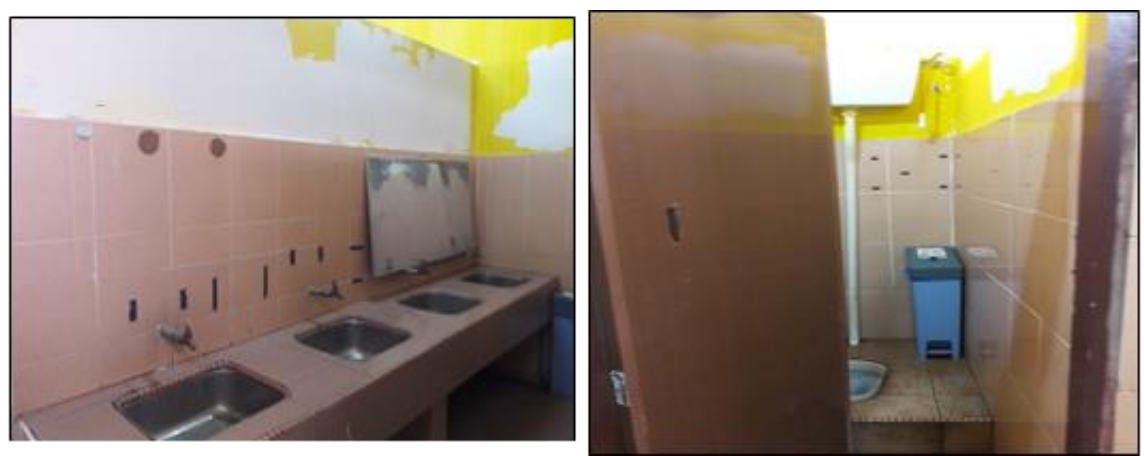

Fig 3. The condition of toilet in DC 


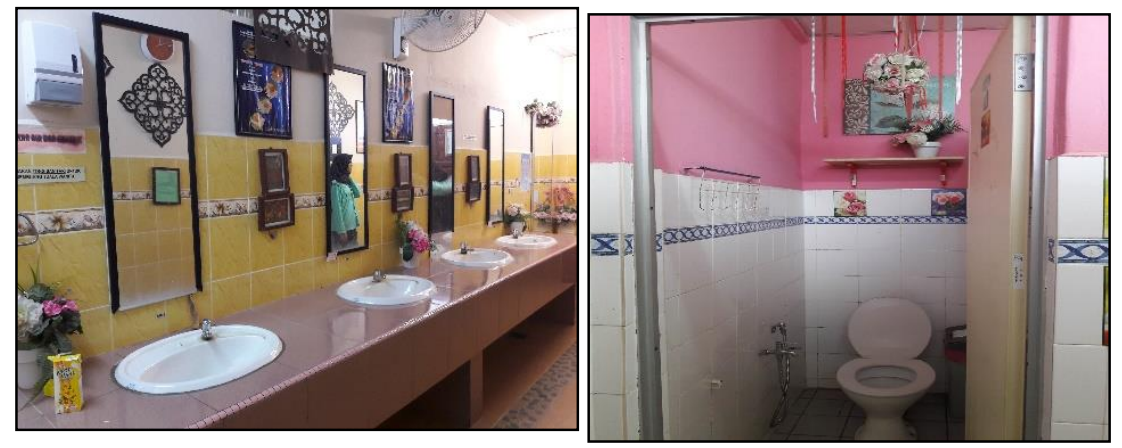

Fig 4. The condition of toilet in DC

\subsection{Classroom}

The classroom is also another hotspot for bullying to occur. The window design plays a role in making the classroom visible or otherwise. The grill that was installed at the school windows prevents clear vision, such as a CD. Also, the class physical environment which included the chairs and the tables were not adequately managed and could create an unpleasant environment for the students. The design of the school windows and the class environment can be seen below.

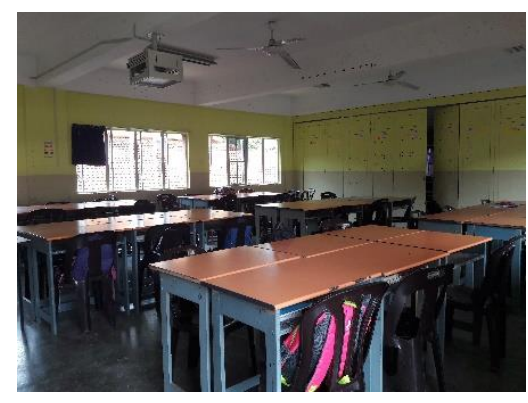

Figure 5. The classroom in $A B$

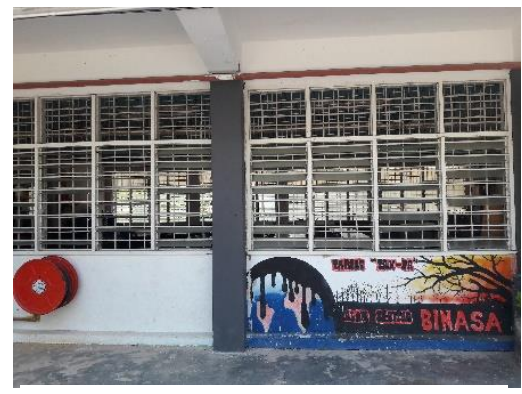

Figure 7. The classroom in CD

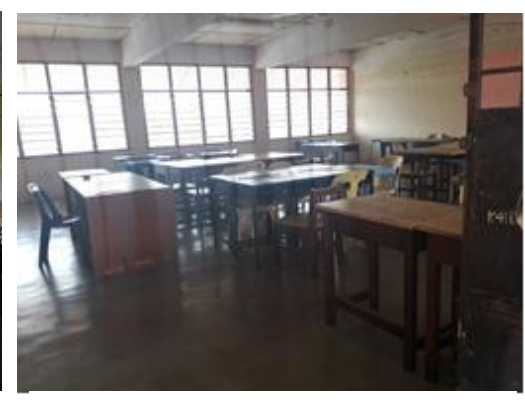

Figure 6 . The classroom in

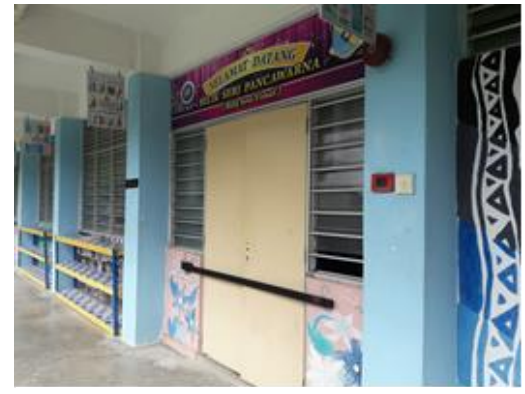

Figure 8. The classroom in DE

\subsection{Canteen}

A canteen area is a place where the students have breakfast and lunch. It is the most crowded place at recess. Many students loiter around which provide the chance of pushing and shoving. A closed-canteen design could reduce the surveillance towards the area while a welcoming environment could give comfort to the student.

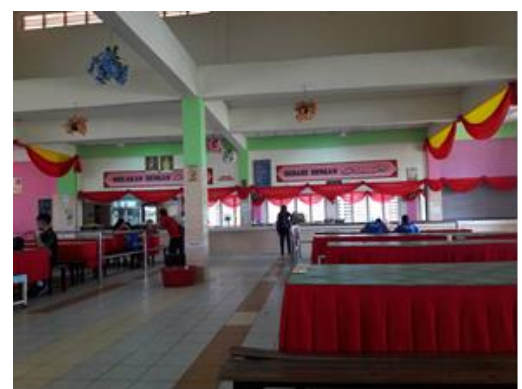

Figure 9. Canteen area in $A B$

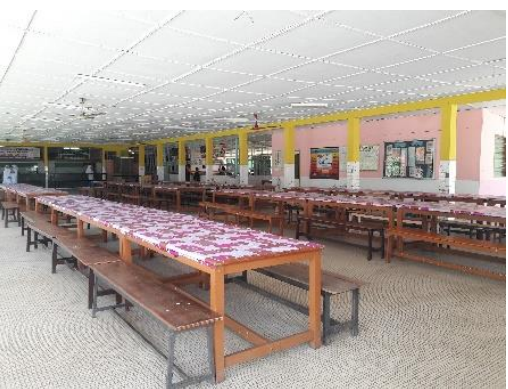

Figure 10. Canteen area in $\mathrm{BC}$ 


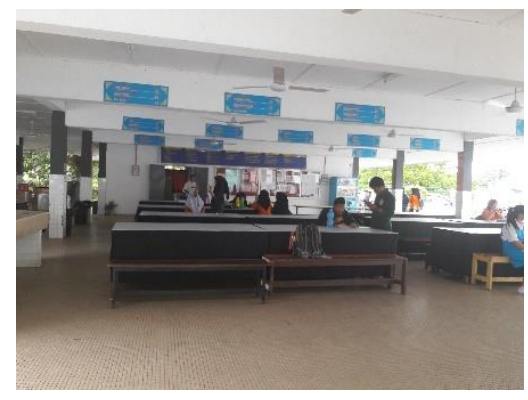

Figure 11.Canteen area in $C D$

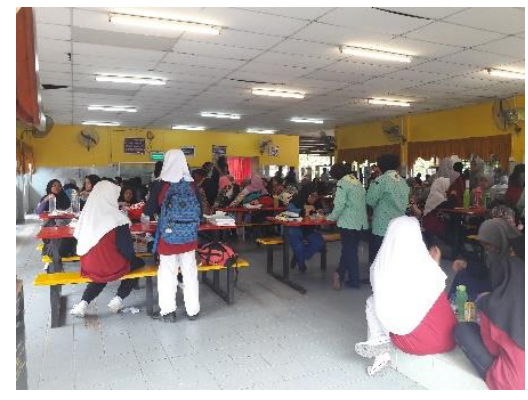

Figure 12.Canteen area in DE

A total of 32 blocks in four schools were observed to indicate the element of territoriality that exists in each school. Table 4 shows the results from the observation of four schools in this study.

\begin{tabular}{|c|c|c|c|c|c|}
\hline \multirow[t]{2}{*}{ School } & \multirow[t]{2}{*}{ Total block } & \multicolumn{2}{|c|}{ Territoriality Element } & \multirow[t]{2}{*}{ Total } & \multirow{2}{*}{$\begin{array}{l}\text { Territoriality } \\
\text { Element per } \\
\text { block }\end{array}$} \\
\hline & & Signage & Ownership & & \\
\hline$A B$ & 6 & 14 & 174 & 188 & 31.33 \\
\hline $\mathrm{BC}$ & 10 & 23 & 97 & 120 & 12 \\
\hline$C D$ & 9 & 14 & 181 & 195 & 21.67 \\
\hline $\mathrm{DE}$ & 7 & 38 & 235 & 273 & 39 \\
\hline Total & 32 & 89 & 687 & 776 & \\
\hline
\end{tabular}

The results indicate that there are seven blocks in School of DE with a total of 273 territoriality elements, nine blocks in School of CD with 95 items, ten blocks in School of BC with 120 items and six blocks in School of $A B$ with 188 elements. The calculation of territoriality element per block results in 39 items per block in $\mathrm{DE}, 21.67$ elements per block in $\mathrm{CD}, 12$ elements per block in $\mathrm{BC}$ and 31.33 elements per block in $A B$. Based on the observation of territoriality elements in four schools, $D E$ and $A B$ had more sense of school ownership in providing students with a positive school environment than $C D$ and $B C$. This was shown by the number of territoriality elements per block in the school. The presence of ownership of these locations has the potential to drastically decrease the prevalence of victimization in schools (Astor et al.,1999). The elements that exist in the school could give the student a sense of belonging and being an integral part of the school. Besides, school DE that had a high element of territoriality had a lower incidence of Bullying compared to school $A B, B C$, and $C D$.

For the surveillance and maintenance elements, the evaluation was done using the percentage level of the items as explained above (observation through a checklist) that was adapted from Sakip et al. (2012). An analysis by ANOVA and Tukey's multiple comparison test was carried out for the four different schools once again. The objectives of this analysis are to know whether there is a difference in surveillance and maintenance in four different schools. An analysis of variance found the effect of different school environments on surveillance was statistically not significant $(F(3,28)=0.637, p=0.598)$. However, there was a significant difference in school maintenance in three different schools $(F(3,28)=11.683 p=0.00)$ of $D E, C D$ and $B C$. The maintenance of a school promotes a positive image for the students. When the level of an area is maintained it becomes one of the factors in ensuring the quality of the activities that take place in it (Durán-Narucki, 2008) and can have a significant impact on whether it will become a hangout place for the bully. A good maintenance strategy directly impacts the fear of crime due to awareness of responsibility and caring for bullying behaviour. It also allows for the continued use of space for its intended purpose. Table 5 below showed the checklist of CPTED elements of four schools.

Table 5. Checklist of CPTED elements in four schools

\begin{tabular}{|c|c|c|c|c|c|c|c|c|c|c|}
\hline \multirow{3}{*}{$\begin{array}{l}\text { CPTED } \\
\text { Territoriality }\end{array}$} & \multirow{3}{*}{$\begin{array}{l}\text { Space } \\
\text { Toilet }\end{array}$} & \multirow{3}{*}{$\begin{array}{l}\text { Item } \\
\text { Signage }\end{array}$} & \multicolumn{2}{|c|}{ School AB } & \multicolumn{2}{|c|}{ School BC } & \multicolumn{2}{|c|}{ School CD } & \multicolumn{2}{|c|}{ School DE } \\
\hline & & & Remarks & Yes/No & Remarks & Yes/No & Remarks & Yes/No & Remarks & Yes/No \\
\hline & & & & $\checkmark$ & & $\sqrt{ }$ & & $\sqrt{ }$ & & $\checkmark$ \\
\hline & & $\begin{array}{l}\text { Flower } \\
\text { Pot }\end{array}$ & & $x$ & & $\sqrt{ }$ & & $x$ & & $\sqrt{ }$ \\
\hline & & $\begin{array}{l}\text { Hand } \\
\text { Wash }\end{array}$ & & $\sqrt{ }$ & & $\sqrt{ }$ & & $x$ & & $\sqrt{ }$ \\
\hline & & Sink & & $\sqrt{ }$ & & $\sqrt{ }$ & & $\sqrt{ }$ & & $\sqrt{ }$ \\
\hline & & Mirror & & $\sqrt{ }$ & & $\checkmark$ & & $x$ & & $\sqrt{ }$ \\
\hline
\end{tabular}




\begin{tabular}{|c|c|c|c|c|c|c|}
\hline & & Lamp & $\sqrt{ }$ & $\checkmark$ & $\checkmark$ & $\checkmark$ \\
\hline & & $\begin{array}{l}\text { Air } \\
\text { Freshener }\end{array}$ & $x$ & $\sqrt{ }$ & $x$ & $\sqrt{ }$ \\
\hline & & Fan & $x$ & $x$ & $x$ & $\sqrt{ }$ \\
\hline & & $\begin{array}{l}\text { Sanitary } \\
\text { Bin }\end{array}$ & $x$ & $x$ & $\checkmark$ & $\checkmark$ \\
\hline & & Clock & $x$ & $x$ & $x$ & $\checkmark$ \\
\hline & Classroom & Signage & $\checkmark$ & $\checkmark$ & $\checkmark$ & $\checkmark$ \\
\hline & & Desk & $\checkmark$ & $\checkmark$ & $\checkmark$ & $\sqrt{ }$ \\
\hline & & Chair & $\checkmark$ & $\checkmark$ & $\checkmark$ & $\checkmark$ \\
\hline & & Fan & $\checkmark$ & $\checkmark$ & $\checkmark$ & $\checkmark$ \\
\hline & & Lamp & $\checkmark$ & $\checkmark$ & $\checkmark$ & $\checkmark$ \\
\hline & & Projector & $\checkmark$ & $x$ & $x$ & $\checkmark$ \\
\hline & & $\begin{array}{l}\text { Whiteboar } \\
d\end{array}$ & $\sqrt{ }$ & $\checkmark$ & $\checkmark$ & $\checkmark$ \\
\hline & & Curtains & $\checkmark$ & $x$ & $x$ & $\checkmark$ \\
\hline & & Dustbin & $\checkmark$ & $\checkmark$ & $\checkmark$ & $\checkmark$ \\
\hline & Canteen & Signage & $\checkmark$ & $\checkmark$ & $\checkmark$ & $\checkmark$ \\
\hline & & Table & $\checkmark$ & $\checkmark$ & $\checkmark$ & $\checkmark$ \\
\hline & & Couch & $\checkmark$ & $\checkmark$ & $\checkmark$ & $\checkmark$ \\
\hline & & Fan & $\checkmark$ & $\checkmark$ & $\checkmark$ & $\checkmark$ \\
\hline & & Lamp & $\checkmark$ & $\checkmark$ & $\checkmark$ & $\checkmark$ \\
\hline & & Flower & $\checkmark$ & $\checkmark$ & $x$ & $\checkmark$ \\
\hline & & Sink & $\sqrt{ }$ & $\checkmark$ & $\checkmark$ & $\checkmark$ \\
\hline & & Mirror & $\checkmark$ & $\checkmark$ & $\checkmark$ & $\checkmark$ \\
\hline & & $\begin{array}{l}\text { Hand } \\
\text { wash }\end{array}$ & $\checkmark$ & $\checkmark$ & $\checkmark$ & $\checkmark$ \\
\hline & & Curtains & $\sqrt{ }$ & $x$ & $x$ & $\checkmark$ \\
\hline & & Dustbin & $\checkmark$ & $\checkmark$ & $\checkmark$ & $\checkmark$ \\
\hline Surveillance & Toilet & $\begin{array}{l}\text { Entrance } \\
\text { Visibility }\end{array}$ & $x$ & $\checkmark$ & $x$ & $\checkmark$ \\
\hline & & Lighting & $\sqrt{ }$ & $\checkmark$ & $\checkmark$ & $\checkmark$ \\
\hline
\end{tabular}




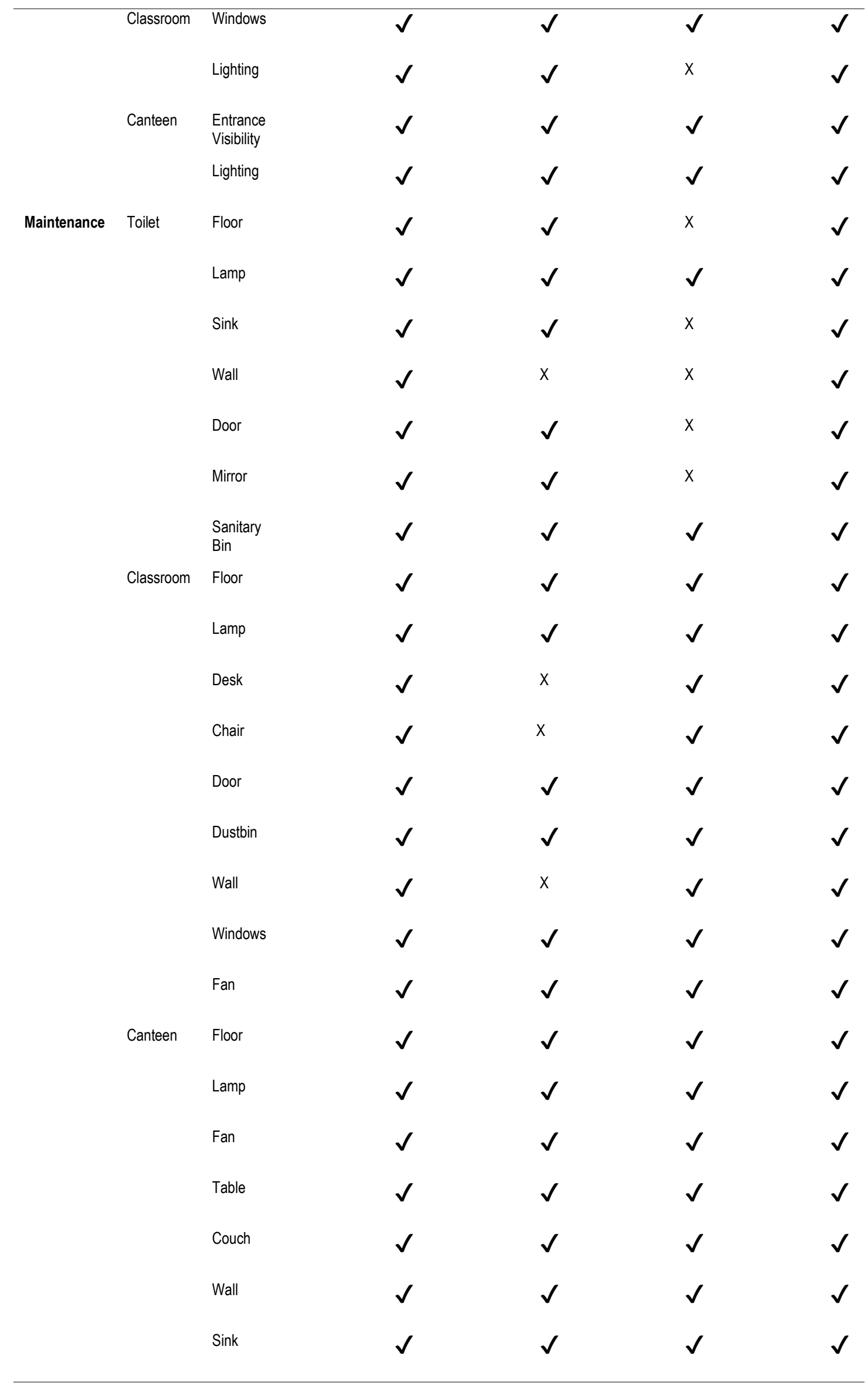




$\begin{array}{llll}\checkmark & \checkmark & \checkmark & \checkmark\end{array}$

\subsection{Conclusion}

Through the analysis above, we were able to evaluate the possibility of Bullying to occur in the isolated area and indicate the place where Bullying is most common to occur. As discussed above, the environment of a secluded place may affect the behaviour of a student. The role of the physical environment such as street layout, building design, lighting and physical decay can change the behaviour of crime (Wilcox et al. 2006). Some places are more exposed to crime than others because of inappropriate physical design, layout (Newman 1972) and overlooked unused spaces. A total of 9 blocks in the School of CD were observed to indicate the element of territoriality that exists in each block which creates an environment in school. Fourteen territoriality elements of signage and 181 elements of ownership were identified in the school. The component of surveillance in each block was surveyed. Generally, the scale of the surveillance element was found to be satisfying at a range between 71 per cent and 90 per cent. However, the arrangement of buildings in this school was not very satisfying as the visibility of student activities, and open spaces from each block were reduced or not fully visible. The maintenance of the school environment included planted elements, litter, school wall painting, and school equipment damage. The school staff appropriately maintained the bedding and dry leaves. However, the maintenance of school cleanliness outside the school was inferior. Paid toilets which were cleaner and well-maintained were provided in the school for the convenience of users because the other bathrooms were dirty and poorly maintained. The facilities that were provided for the students were not well maintained in the school. This created an unpleasant environment in the school.

This research suggests that there can be a potential relationship between bullying possibility and physical environment, highlighting that Bullying is not a result solely of individuals and their interactions only (Migliaccio et al., 2017). There are school areas which were identified to be the most common area where Bullying occurs, such as the classroom when the teacher is absent, toilet, and canteen. However, the students often avoid being alone behind the school building because of the fear of being bullied. The density surfaces suggest that, in some areas, the possibility of Bullying to occur can be diffusing from one location to another location due to the student's behaviour in spending their recess time which gives them more comfort in certain areas. Thus, the physical environment in certain areas plays a vital role in providing a sense of comfort and safety. Migliaccio et al. (2017) had suggested that by clearly identifying the regularity of students bullying in school areas with time would lead to a better understanding on how the physical environment interacts with social contexts to shape the landscape of Bullying.

Thus, in the analysis of the physical environment, which is based on the CPTED approach, it can be identified that some of the physical environment could create a poor environment if poorly maintained. A better arrangement and design of school blocks are also needed to increase the surveillance of students.

\section{Acknowledgement}

The authors gratefully acknowledge the Royal Malaysian Police (PDRM), Ministry of Higher Education by the Malaysian Government to support this research by the Fundamental Research Grant Scheme (FRGS) of (600-RMI/FRGS5/3(126/2015)).

\section{References}

Anastasia, LS and EE John. 2007. "Crime Prevention and Active Living." American Journal of Health Promotion 21:380-89.

Andershed, Henrik, Margaret Kerr, and Håkan Stattin. 2001. "Bullying in School and Violence on the Streets: Are the Same People Involved?" Journal of Scandinavian Studies in Criminology and Crime Prevention 2(1):31-49.

Astor, Ron Avi, Heather Ann Meyer, and William J. Behre. 1999. "Unowned Places and Times: Maps and Interviews About Violence in High Schools." American Educational Research Journal 36(1):3-42.

Atlas, Rona S. and Debra J. Pepler. 1998. "Observations of Bullying in the Classroom." Journal of Educational Research 92(2):86-99.

Craig, Wendy M., Debra J. Pepler, and Rona Atlas. 2000. "Observation of Bullying in the Playground and in the Classroom." School Psychology International 21(1):2236 .

De Vaus, D. A. (1986) Surveys in Social Research, London, Academic Division of Unwin Hyman Ltd

Devellis, R. F. (1991) Scale Development: Theory and Application., Thousand Oaks, CA, Sage.

Elwood, S. (2002). GIS use in community planning: A multi-dimensional analysis of empowerment. Environment and Planning A, 34, 323-341. Fite, Paula J. et al. 2013. "Patterns of Victimization Locations in Elementary School Children:

Effects of Grade Level and Gender." Child and Youth Care Forum 42(6):585-97.

Fyfe, D. A., Holdsworth, D. W., \& Weaver, C. (2009). Historical GIS and visualization: Insights from three hotel guest registers in central pennsylvania, 1888-1897. Social Science Computer Review, 27(3), 348-362. doi:10.1177/0894439308329762. 
Johnson, Sarah Lindstrom. 2009. "Improving the School Environment to Reduce School Violence: A Review of the Literature." Journal of School Health 79(10):451-65. Kitchen, T. and RH Schneider. 2007. Crime Prevention and the Built Environment.

Kikuchi, G., Amemiya, M., \& Shimada, T. (2012). An analysis of crime hot spots using GPS tracking data of children and agent-based simulation modelling. Annals of GIS, 18(3), 207-223. DOI:10.1080/ 19475683.2012.691902.

Kubrin, C., Messner, S., Deane, G., McGeever, K., \& Stucky, T. (2010). Proactive policing and robbery rates across US cities. Criminology, 48, 57-97.

Law, J., Quick, M., \& Chan, P. (2014). Bayesian Spatio-temporal modeling for analysing local patterns of crime over time at the small-area level. Journal of Quantitative Criminology, 30(1), 57-78. doi:10.1007/s10940-013-9194-1.

Lee, Soyeon and Mikyoung Ha. 2015. "The Duality of Visibility : Does Visibility Increase or Decrease the Fear of Crime in Schools' Exterior Environments ?" Journal of Asian Architecture and Building Engineering 14(1):145-52.

Liebermann, S. and T. Kruger. 2004. "Crime Prevention Through Environmental Design (CPTED)." in the 9th International Conference on Crime Prevention Environmental Design.

Lorenc, Theo et al. 2013. "Fear of Crime and the Environment : Systematic Review of UK Qualitative Evidence."

Melde, Chris and Finn-Aage Esbensen. 2009. "The Victim-Offender Overlap and Fear of InSchool Victimization." Crime \& Delinquency 55(4):499-525.

Migliaccio, Todd, Juliana Raskauskas, and Mathew Schmidtlein. 2017. "Mapping the Landscapes of Bullying." Learning Environments Research 20(3):365-82. Retrieved ("http://dx.doi.org/10.1007/s10984-017-9229-x).

Min, Jung Kim, Richard F. Catalano, Kevin P. Haggerty, and Robert D. Abbott. 2011. "Bullying at Elementary School and Problem Behaviour in Young Adulthood: A Study of Bullying,

Violence and Substance Use from Age 11 to Age 21." Criminal Behaviour and Mental Health 21:136-44.

Nunnally, J. C., \& Bernstein, I. H. (1994). Psychometric Theory. New York: McGraw-Hill.

Olweus, Dan. 1993. "Bullies on the Playground: The Role of Victimization." Pp. 85-128 in Children on Playgrounds: Research Perspectives and Applications. SUNY Press.

Olweus, Dan. 2011. "Bullying at School and Later Criminality: Findings from Three Swedish Community Samples of Males." Criminal Behavior and Mental Health 21:15156 .

Perkins, DD, JW Meeks, and RB Taylor. 1992. "The Physical Environment of Street Blocks and

Resident Perceptions of Crime and Disorder: Implications for Theory and Measurement." Journal of environmental psychology 12:21-34.

Poyner, B. 1983. Design against Crime: Beyond Defensible Space. Retrieved April 14, 2016 (https://www.ncjrs.gov/App/Publications/abstract.aspx?ID=92652).

Ratcliffe, J. H., Taniguchi, T., Groff, E. R., \& Wood, J. D. (2011). The Philadelphia foot patrol experiment: A randomized controlled trial of police patrol effectiveness in violent crime hotspots. Criminology, 49(3), 795-831. doi:10.1111/j.1745-9125.2011.00240.x.

Rapp-paglicci, Lisa, Catherine N. Dulmus, Karen M. Sowers, and Matthew T. Theriot. 2004. "' Hotspots ' for Bullying." Journal of Evidence-Based Social Work 1(2-3):13141.

Renda, Jennifer, Suzanne Vassallo, and Ben Edwards. 2011. "Bullying in Early Adolescence and Its Association with Anti-Social Behaviour, Criminality and Violence 6 and 10 Years Later." Criminal Behaviour and Mental Health 21:117-27.

Reynald, Danielle M. 2014. "Environmental Design and Crime Events." Journal of Contemporary Criminal Justice 31(1):71-89.

Roland, Erling and David Galloway. 2002. "Classroom Influences on Bullying." Education Research 44(3):299-312.

Sakip, Siti Rasidah Md, Noraini Johari, and Mohd Najib Mohd Salleh. 2012. "The Relationship between Crime Prevention through Environmental Design and Fear of Crime." Procedia - Social and Behavioral Sciences 68:628-36.

Sourander, Andre et al. 2011. "Bullying at Age Eight and Criminality in Adulthood: Findings from the Finnish Nationwide 1981 Birth Cohort Study." Social Psychiatry and Psychiatric Epidemiology 46(12):1211-19.

Stephenson, P. and D. Smith. 1989. "Bullying in the Junior School." Pp. 45-57 in Bullying in schools.

Vidourek, Rebecca A., Keith A. King, and Ashley L. Merianos. 2016. "School Bullying and

Student Trauma: Fear and Avoidance Associated with Victimization." Journal of Prevention \& Intervention in the Community 44(2):121-29.

Wilcox, Pamela, Michelle Campbell Augustine, and Richard R. Clayton. 2006. "Physical Environment and Crime and Misconduct in Kentucky Schools." The Journal of Primary Prevention 27(3):293-313. 